\title{
4-H RECYCLING ADVENTURES
}

\author{
R.E. CYCLER \& THE BREEZERS
}

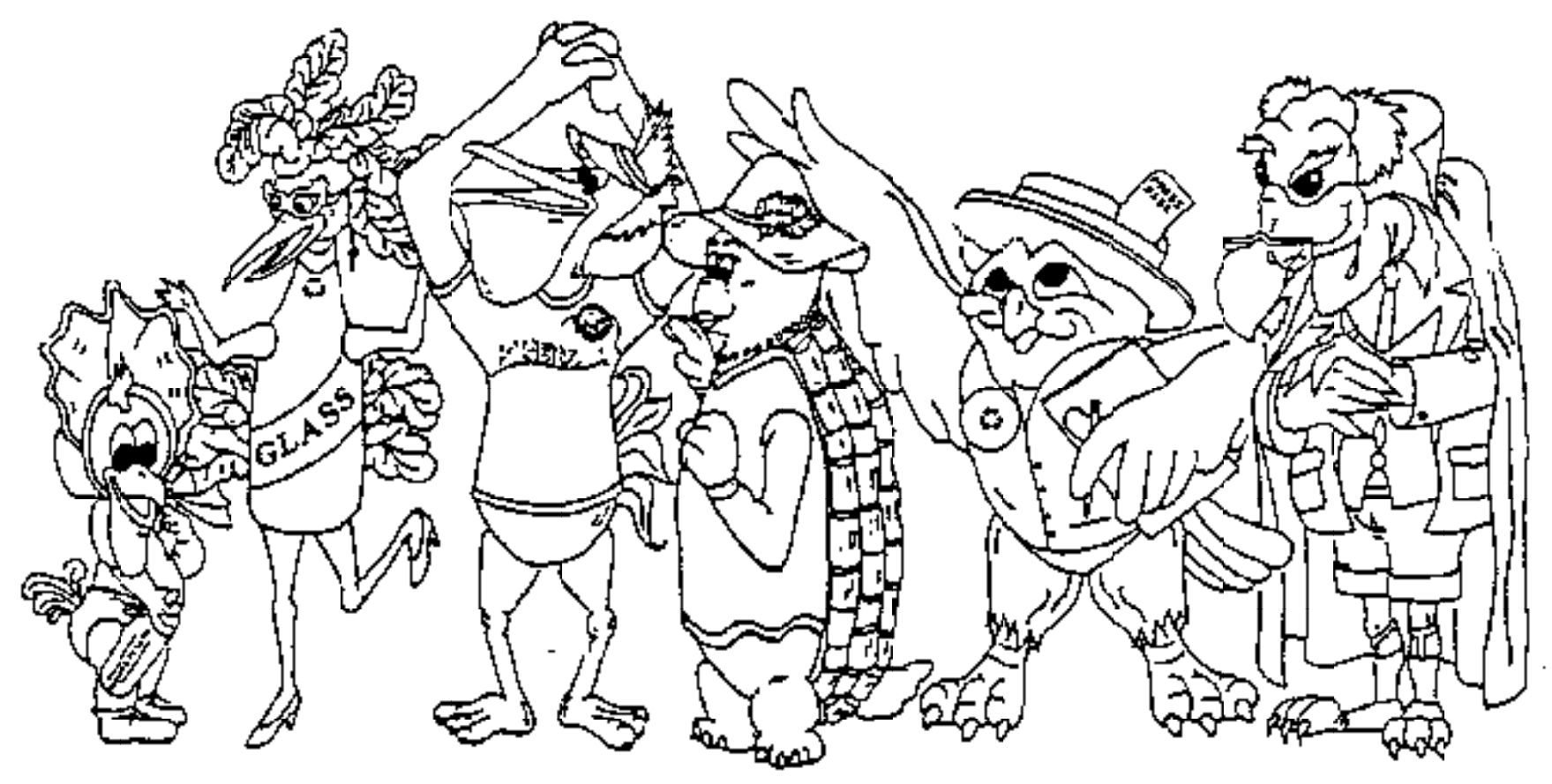

\section{An Educational Waste Management Project Kit}

Produced by the Department of 4-H and Other Youth Programs, Florida Cooperative Extension Service, Institute of Food and Agricultural Sciences. University of Florida, April, 1992. Reviewed June 2002.

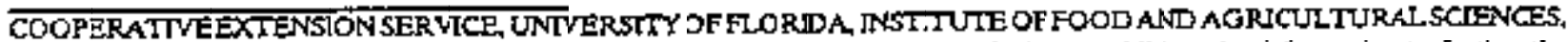

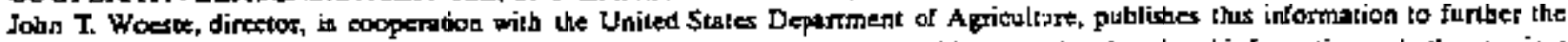

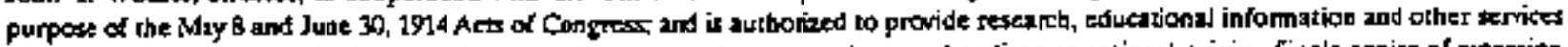

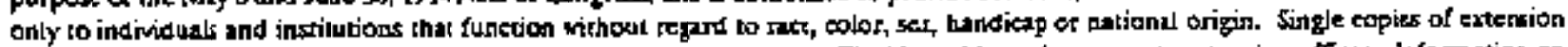

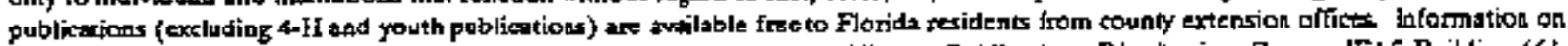

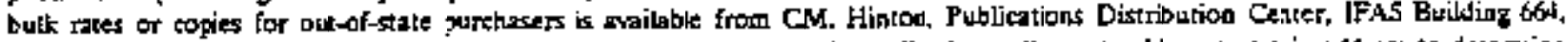

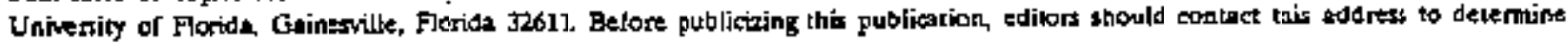
mailability. Frinted $4 / \%$ ? 


\title{
4-H RECYCLING ADVENTURES
}

\section{R.E. CYCLER \& THE BREEZERS}

\section{An Educational Waste Management Project Kit}

\author{
Recycling Adventures was originally created by a team of University of Florida County Extension agents and \\ cooperators in Broward and Palm Beach counties including: \\ Project Directors: Sandy Behnke and Paula Stewart \\ Authors: Sandra Brubaker, Carol Anne Schiller, Paula Stewart \\ Editorial Committee: Sandy Behnke, Elizabeth Brisset, Sandra Brubaker, Jodi John, Paula Stewart \\ Graphic Design: Ellen Bailey, David Dishman, Diane Hammer, John Mazerelle, Beth Ortman \\ Music: Sandra Brubaker, Norm Eckels, Carol Anne Schiller, Hollond Schiller, Pepe Serventi \\ Audio Production: Orazio Spagnardi
}

This team is especially appreciative of the support and cooperation provided by several Broward County Government divisions including Office of Environmental Services: Solid Waste and Management Divisions; and Public Information: Graphics Division.

We are also pleased to acknowledge that funding was provided for the original curriculum's development by Broward County Office Environmental Services* through a grant from the Florida Department of Environmental Regulations; and Florida Energy Extension Service through a grant from the Governor's Energy Office.

With technical review and assistance from members of the Cooperative Extension Service Environmental Education Design Team (FL605) and with permission of Broward County, these curriculum materials have been edited and adapted for introduction and utilization throughout the state.

This curriculum package was adapted and prepared by Craig Miller, Educational Resources and Publications Coordinator and Joy Cantrell, Assistant Professor and 4-H Youth Development Curriculum Specialist, Department of 4-H and Other Youth Programs, Institute of Food and Agricultural Sciences, University of Florida.

Other faculty serving on the Environmental Educational Design Team are Marie Hammer, Extension Specialist, Department of Home Economics; Nancy Arny Pywell, Extension Specialist, Department of Forestry; Randy Brown, Extension Specialist, Department of Soils; Helen Whiffen, Energy Specialist, Energy Extension Service; Elva Farrell, 4-H Youth Development Extension Agent, Sarasota County; Albert Fuller, County Extension Director, Levy County; Shirley Bond, 4-H Youth Development Extension Agent, Hillsborough County.

We extend sincere thanks to the U.S. SUGAR CORPORATION for investing in the adaptation, production, distribution of the curriculum package and instructional workshops that are enabling Extension faculty to launch this program throughout the state...AN INVESTMENT IN OUR WORLD THROUGH TODAY'S YOUTH.

*The Recycling Adventures Educational Kit is available for public use. Copyrights are pending on the Broward County Recycling Mascots, R.E. Cycler and the BREEZers. They can be used as is with credit to Broward County. Any additional questions about the use of the characters should be directed to the Broward County Integrated Waste Management Office Countyside Recycling Program at (305) 978-1164.

Printed 4/92 


\title{
PREFACE
}

\section{4-H RECYCLING ADVENTURES}

\section{An Environmental Education and Waste Management Curriculum for Young People}

\begin{abstract}
The new Florida 4-H Environmental Education curriculum, OUR NATURAL WORLD, includes a basic premise, i.e., our environment is a web of cooperation and interdependence. One of the five key components of the curriculum is Waste Management.
\end{abstract}

4-H RECYCLING ADVENTURES is the portion of the 4-H Waste Management curriculum that is designed to help 5 11 year old youths to understand the environmental and economic issues associated with waste. Additional curriculum packages are being designed for older youth.

To the informed Florida citizen it is not surprising that waste management commands such a significant portion of the total 4-H Environmental Education curriculum. With enactment of Senate Bill 1192 in 1988, Florida municipalities were charged with the task of reducing the waste stream by $30 \%$. A significant part of the statewide educational program to achieve this goal focuses on our children. An investment in their knowledge, understanding and attitudes about our natural environment can not be ignored now or in the future.

In 4-H RECYCLING ADVENTURES, we are particularly interested in helping young people develop a personal environmental ethic and to understand each person's individual impact on waste generation and management. 


\section{TABLE OF CONTENTS}

\section{INTRODUCTION}

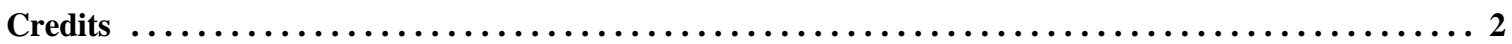

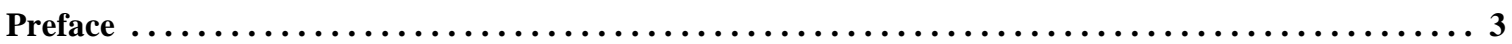

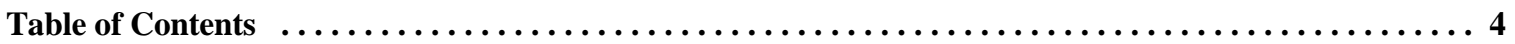

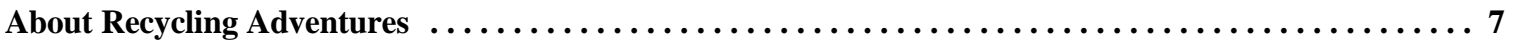

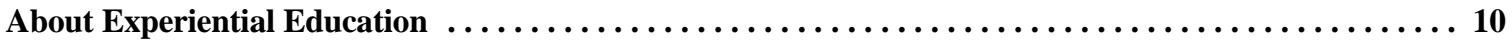

II. RECYCLING ADVENTURES

ADVENTURE 1: Billy's Adventures...In Search of Hidden Treasures $\ldots \ldots \ldots \ldots \ldots \ldots \ldots \ldots \ldots$ A1-1

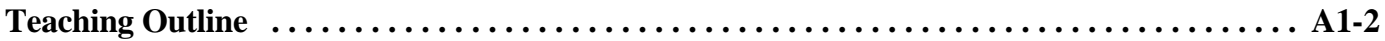

Levels 1 À2 À 3

Waste Basics .............................................. A1-3

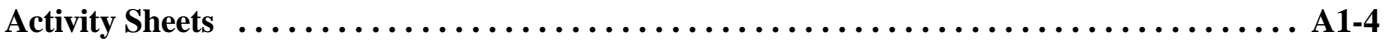

Puppet Show Script .................................... A1-8

COPY ME Sheet

Hidden Treasure - Puppet Show Stage..$\ldots \ldots \ldots \ldots \ldots \ldots \ldots \ldots \ldots \ldots$ A1-19

Letter to Parents

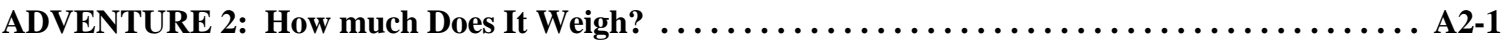

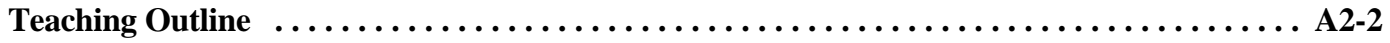

Levels 1 À2 À3

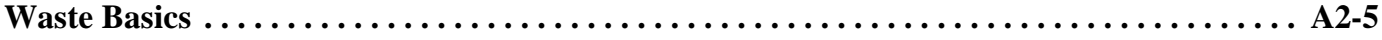

Activity Sheets

Trash Bag Weigh In! ................................. A2-7

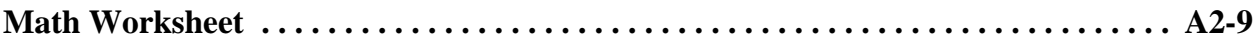

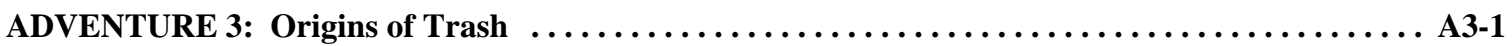

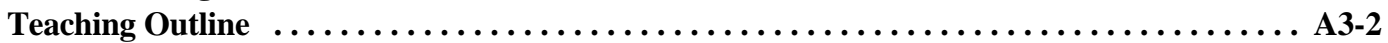

Levels 1 À2 À3

Waste Basics ............................................ A3-5

Activity Sheets

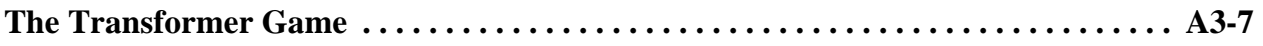

COPY ME Sheets

Animal/Plant/Mineral Resource Sheets

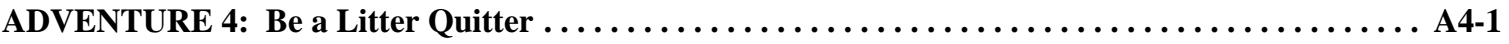

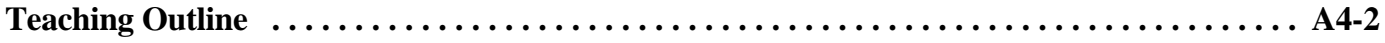

Levels 1 À2 À3

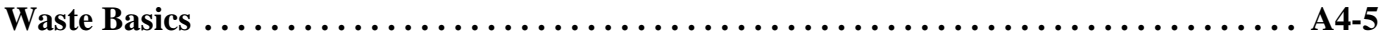

Activity Sheets

Litter Pick-Up ..................................... A4-7

Artistic Litter Collage . . . . . . . . . . . .

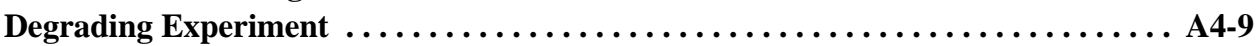




\section{TABLE OF CONTENTS}

ADVENTURE 5: Recycling...Join the BREEZers $\ldots \ldots \ldots \ldots \ldots \ldots \ldots \ldots \ldots \ldots \ldots \ldots \ldots \ldots \ldots \ldots$ A5-1

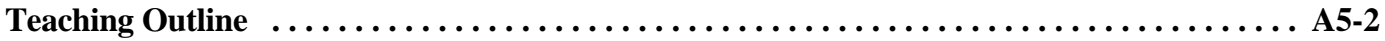

Levels 1 À2 À3

Waste Basics

Activity Sheets

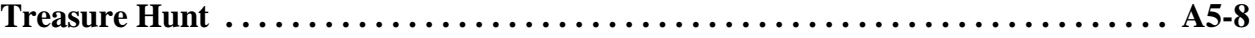

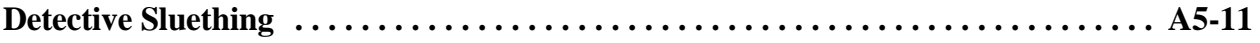

COPY ME Sheets

R.E. Cycler

Count Ebenezer Waste

Can-Do-Katie

Greta Glass

Write-on-Willy

Peli-Cycler

Recycle Symbol

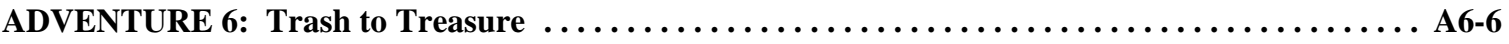

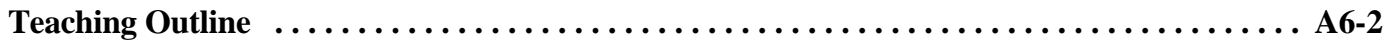

Levels 1 À2 À3

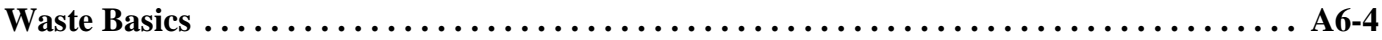

Activity Sheets

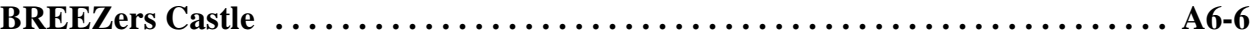

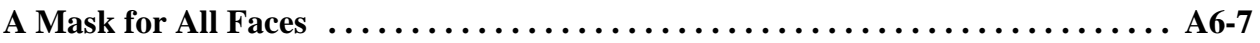

Peli's Planter ............................................ A6

Mom's Apple Baker .................................. A6-10

Katie's Recycling Badge .................................. A6-11

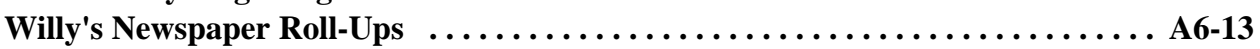

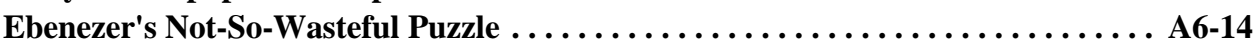

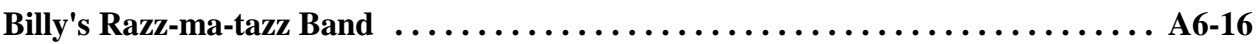

Greta's Mini Bin Game ................................... A6-19

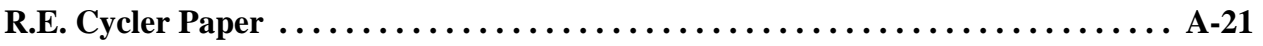

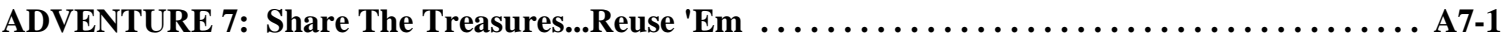

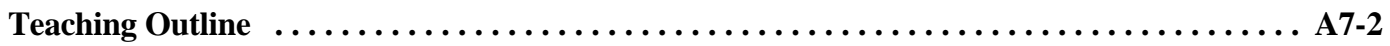

Levels 1 À2 À3

Waste Basics $\ldots \ldots \ldots \ldots \ldots \ldots \ldots \ldots \ldots \ldots \ldots \ldots \ldots \ldots \ldots \ldots \ldots \ldots \ldots \ldots \ldots \ldots \ldots \ldots \ldots, \mathbf{A} 7-5$

Activity Sheets

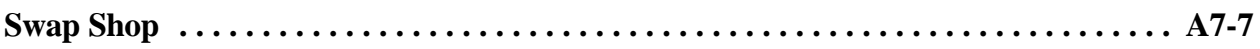

Good Samaritan ................................. A7

As Is Sale...Everything Must Go! ........................ A7-9

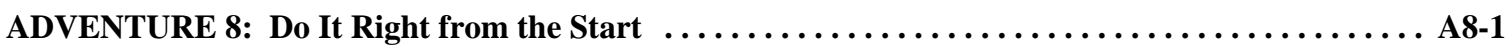

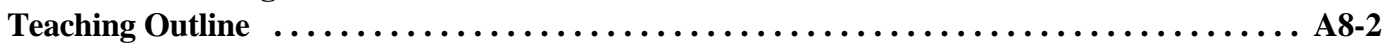

Levels 1 À2 À3

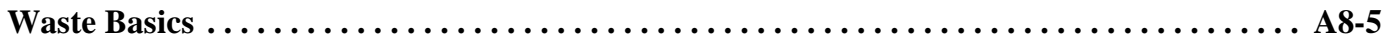

Activity Sheets

Wise Shopper.$\ldots \ldots \ldots \ldots \ldots \ldots \ldots \ldots \ldots \ldots \ldots \ldots \ldots \ldots \ldots \ldots \ldots \ldots \ldots \ldots$ A8-9

Package it Right $\ldots \ldots \ldots \ldots \ldots \ldots \ldots \ldots \ldots \ldots \ldots \ldots \ldots \ldots \ldots \ldots \ldots \ldots \ldots \ldots \ldots \ldots \ldots \ldots, 12$ 


\section{TABLE OF CONTENTS}

ADVENTURE 9: Dealing with Leftovers...Dump or Serve? ...................... A9-1

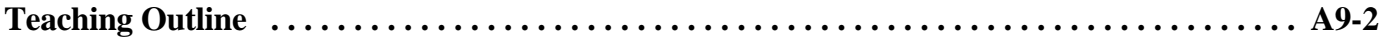

Levels 1 À 2 À3

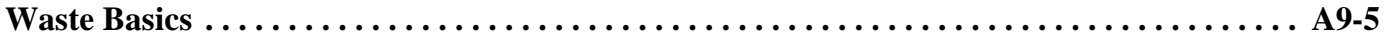

Activity Sheets

Overflowing Landfills .................................. A9-8

A Rotten Idea...Or Is It? .................................. A9-9

Life in a Landfill...Will It Ever End? ........................ A9-11

Building a Landfill...It Isn't a Dump! ....................... A9-13

ADVENTURE 10: Put It All Together...Billy's Waste Wise Game

Teaching Outline

Levels 1 À 2 À3

Waste Basics

Activity Sheets

Billy's Waste Wise Game $\ldots \ldots \ldots \ldots \ldots \ldots \ldots \ldots \ldots \ldots \ldots \ldots \ldots \ldots \ldots$ A10-8

GLOSSARY

III. SUPPLEMENTAL ACTIVITIES

Dumps 'N Dinosaurs

Billy's Recycling Match

More Ideas!

Recycling Pledge

Puppet Show Script (Short Version)

IV. COPY ME Sheets

Puppet Show Songs

Treasure Map

My Litter Notebook

My Shopping Notes

Animal/Plant/Mineral Resource Sheet

Cash Register

BREEZE Dollars

Puppet Show Script(Large Print)

V. EVALUATION \& RECOGNITION

Certificate

Teacher's Evaluation Form 


\section{About Recycling Adventures}

The development of this 4-H Environmental Education Project Kit was driven by two basic principles.

1. Learning about waste can be fun! The kit provides simple and inexpensive, yet fun and creative activities that teach youth about major waste management concepts, including the four R's: reduce, reuse, reject, and recycle.

2. $\quad$ 4-H volunteer teaching activities must be ready-to-use. This project packages supplies and support materials needed to conduct recycling activities into an easy-to-use format. It was designed to be teacher friendly and takes much of the guesswork out of teaching this subject.

\section{LEVELS}

This project was developed for youth ages 5-11. Both group and individual activities encourage participation and action in all aspects of waste management. Activities were developed to address the needs of young people in the following three levels:

Level 1 - Preschool to First Grade - 5-6 year olds

Level 2 - Second and Third Grades - 7-8 year olds

Level 3 - Fourth and Fifth Grades - 9-11 year olds

Teachers and volunteers are encouraged to select learning activities at the level that is most suitable to their youth. The overall intent is to facilitate learning and to spark creativity in both teachers and youth.

\section{CONTENTS}

The following resources are contained in the educational kit:

! LEADER'S GUIDE - This three-ring notebook contains complete, easy-to-read outlines for lessons, called "Adventures," background information divided into bite-size pieces, called "Waste Basics," and cameraready COPY ME pages for students. Youth explore the problems of solid waste management through ten Adventures. Adventure 1, an original puppet show, stresses all aspects of the waste management loop. Adventures 2 through 9 address eight parts of this process. Finally, the last Adventure reinforces what the students have learned and charges them to become a part of waste management solutions. For more details about the lessons, see ADVENTURE PROFILES.

! PUPPET SHOW - a twenty-five minute puppet show is the foundation of this project. The problems and solutions to waste management are viewed through the eyes of a little boy named Billy. Through an encounter with a friendly pelican, R.E. Cycler, Billy learns about the valuable treasures that he finds in a trash can. From litter to recycling to landfills, R.E. shows Billy how he can save the treasures of the earth. The BREEZers (a family of recycling-conscious animals) and Count Ebenezer Waste (the garbage-loving vulture) round out the cast of characters.

$! \quad$ TRASH "STARTER" KIT (AND OTHER USEFUL SUPPLIES) - This educational enrichment kit has taken much of the leg work out of starting a waste management program in community 4-H clubs, schools, day care centers, and other facilities. We have compiled many of the essential supplies needed to conduct the puppet show and learning activities. Leaders are encouraged to collect additional items to illustrate waste management concepts. 
! DUMPS 'N DINOSAURS GAME - An original board game called "Dumps 'N Dinosaurs" accompanies this kit. Designed for small groups (1 to 4 players), it reinforces waste management concepts while serving as a simple counting exercise for younger children.

! SUPPLEMENTAL ACTIVITIES - A garbage glossary, ideas for field trips, and games round out the materials packaged in this Leader's Guide.

\section{ADVENTURE PROFILES}

A brief description of the ten Recycling Adventures follows: ADVENTURE 1: BILLY'S ADVENTURES: IN SEARCH OF HIDDEN TREASURES ... A Puppet Show

This interactive puppet show introduces youth to all waste management concepts embodied in the Recycling Adventures Package. Through the medium of a puppet show, R.E. Cycler and the BREEZers reveal the concepts of litter, recycling, reusing, reducing, and resource recovery.

\section{ADVENTURE 2: HOW MUCH DOES IT WEIGH:}

To begin to understand Florida's solid waste dilemma, youth must realize that we produce a lot of trash each and every day! This adventure helps youth visualize the daily trash volume generated by Floridians, identify who produces garbage, and recognize how lifestyle and population affect this amount. Lesson\meeting topics include activities such as "Trash Bag Weigh-in," a group game that trashes the "earth," and math-oriented exercises that involve addition, subtraction, multiplication, and division. Level 2 and 3 students calculate the amount of trash generated by an individual, a family, and Florida citizens.

\section{ADVENTURE 3: ORIGINS OF TRASH}

In order to appreciate the resource value of garbage, youth must recognize that everyday items are made from other materials. Through the use of a "Transformer Game," youth learn that trash originates from natural resources (plants, animals, and minerals), recognize that these limited resources are valuable treasures, and can identify those resources used to produce some common products. In older levels, youth progress from identifying the origin of product contents (milk from animals) to the origin of product packaging (milk jugs made of HDPE plastic).

\section{ADVENTURE 4: BE A LITTER QUITTER}

One way many people dispose of trash is by littering ... throwing the item on the ground, in the water, or on the sidewalk. Youth learn about the problems of litter in the environment (cost, aesthetics, health) by participating in a litter pick-up. Activities range from creating a litter collage for display to competing among teams to collect the most litter. Older youth also predict the amount of trash collected and experiment with the degradation capacities of litter.

\section{! ADVENTURE 5: RECYCLING ... JOIN THE BREEZers!}

A more acceptable and effective method of disposing trash is to recycle. This adventure teaches about commercial recycling of garbage, such as glass, aluminum cans, tin cans, paper, and certain plastics. Youth learn the value of recycling, what materials are recyclable, how to separate for recycling and ways to close the recycling loop. Activities such as "Treasure Hunt" and "Detective Sleuthing" provide youth an opportunity to actively participate in recycling their own trash. Math calculations and charting activities are included in the higher levels. 


\section{ADVENTURE 6: TRASH TO TREASURE}

The most important part of the recycling loop is to create and use new products from sorted recyclables. Adventure 6 emphasizes this point and shows youth the important role they play in the recycling loop and how to keep that loop from breaking. By transforming typical garbage into new, fun, sometimes zany items, they learn that not all recycling has to be done commercially. Teachers may choose one of ten activities for this adventure, and use the other nine in art, music, social studies, math, or science classes throughout the year. The ten activities are listed below:

\author{
! BREEZers Castle \\ ! A Mast for All Faces \\ ! Ebenezer's Not-So-Wasteful Puzzle \\ ! Willy's Newspaper Roll-ups \\ ! Billy's Rzaa-ma-tazz Band
}

\author{
! Katie's Recycling Badge \\ ! Peli's Planter \\ ! Greta's Mini-bin Game \\ ! Mom's Apple Baker \\ ! R.E. Cycler Paper
}

\section{ADVENTURE 7: SHARE THE TREASURES . . . REUSE 'EM}

"Beauty is in the eyes of the beholder." And so it goes for trash! Youth will learn that a used item designated as "trash" by one person can become a useful "treasure" for another. Practical reusing experiences appropriate for all age levels encourage swapping, donating, fixing up, and selling used items. Older youth gain skills in organizing and planning activities through group experiences.

\section{ADVENTURE 8: DO IT RIGHT FROM THE START}

Stopping waste before it starts is another day to effective solid waste management. Youth recognize that preventing waste in the first place is less costly than trying to get rid of it later. They learn how to become more observant and environmentally aware consumers. Levels 1 and 2 youth "buy" products using BREEZ Dollars in "Wise Shopper" grocery store game, while level 3 youth play "Package It Right," a version of the popular game show, "The Price is Right."

\section{ADVENTURE 9: DEALING WITH LEFTOVERS . . . DUMP OR SERVE?}

After we have done our best to reduce, reuse and recycle, where do the leftovers go? Youth learn that some of the remaining trash can still be used to generate heat and energy and make soil additives. Various demonstrations and experiments illustrate two more solid waste management options, incineration and composting. Youth also explore the "resting ground" for the remaining trash: landfills: how are they constructed, what happens to materials (trash) when placed there, and why does Florida need to reduce the amount of trash going to landfills? Level 3 youth prepare an "investigative" report on the technical and social aspects of landfills, then present their findings in a 20/20-style program.

\section{ADVENTURE 10: PUT IT ALL TOGETHER ... BILLY'S WASTE WISE GAME}

Just as Billy discovered the complete picture of garbage on his beach outing, so too must youth put together all the solid waste pieces. This last adventure incorporates "Billy's Waste Wise Game" to summarize the major concepts discussed in the previous lessons. Youth are invited to join the BREEZers by pledging to do their part to reduce, reuse, and recycle Florida's waste stream. 